\title{
Optimization of fermentation conditions for an Escherichia coli strain engineered using the response surface method to produce a novel therapeutic DNA vaccine for rheumatoid arthritis
}

\author{
Juan Long ${ }^{\dagger}$, Xiao Zhao ${ }^{\dagger}$, Fei Liang, Nan Liu, Yuying Sun and Yongzhi Xi ${ }^{*}$ (i)
}

\begin{abstract}
Background: Fermentation condition optimization and nutrients screening are of equal importance for efficient production of plasmid DNA vaccines. This directly affects the downstream purification and final quality and yield of plasmid DNA vaccines. The present study aimed to optimize the fermentation conditions for high-throughput production of therapeutic DNA vaccine pcDNA-CCOL2A1 by engineered Escherichia coli DH5a, using the response surface method (RSM).

Results: We hypothesized that optimized fermentation conditions significantly increase the yield of pcDNA-CCOL2A1 therapeutic DNA vaccine, a novel DNA vaccine for treating rheumatoid arthritis (RA). Single-factor analysis was performed to evaluate the optimal basal culture medium from LB, $2 \times Y$ T, TB, M9 (Glycerol) and M9 (Glucose), respectively. Thereafter, the Plackett-Burman design (PBD) was used to ascertain the three most significant factors affecting the vaccine yields, followed by the paths of steepest ascent to move to the nearest region of maximum response. Initial screening through the PBD revealed that the most key factors were peptone, mannitol, and inoculum concentration. Subsequent use of RSM was further optimized for the production of therapeutic DNA vaccine pcDNA-CCOL2A1 through Box-Behnken design (BBD). The final optimized fermentation conditions were as follows: peptone, $25.86 \mathrm{~g} / \mathrm{L}$; mannitol, $8.08 \mathrm{~g} / \mathrm{L}$; inoculum concentration, $\mathrm{OD}=0.36$. Using this statistical experimental design, the yield of therapeutic DNA vaccine pCDNA-CCOL2A1 markedly increased from $223.37 \mathrm{mg} / \mathrm{L}$ to339.32 mg/L under optimal conditions, and a 51.9\% increase was observed compared with the original medium.

Conclusions: The present results provide a basis for further production of high-quality and high-yield therapeutic DNA vaccine pCDNA-CCOL2A1 in pilot-scale and even industrial-scale.
\end{abstract}

Keywords: Therapeutic DNA vaccine, Chicken type II procollagen, Engineered Escherichia coli, Optimizing fermentation conditions, Rheumatoid arthritis

\footnotetext{
* Correspondence: xiyz@yahoo.com

†uan Long and Xiao Zhao contributed equally to this work.

Department of Immunology and National Center for Biomedicine Analysis,

Beijing 307 Hospital, No.8, Dongda Ave, Fengtai District, Beijing 100071,

People's Republic of China
}

(c) The Author(s). 2018 Open Access This article is distributed under the terms of the Creative Commons Attribution 4.0 International License (http://creativecommons.org/licenses/by/4.0/), which permits unrestricted use, distribution, and reproduction in any medium, provided you give appropriate credit to the original author(s) and the source, provide a link to the Creative Commons license, and indicate if changes were made. The Creative Commons Public Domain Dedication waiver (http://creativecommons.org/publicdomain/zero/1.0/) applies to the data made available in this article, unless otherwise stated. 


\section{Background}

Therapeutic DNA vaccines, especially antigen-specific tolerizing DNA vaccines, as novel therapeutic strategies for rheumatoid arthritis (RA), have displayed marked advantages compared with current therapies including disease-modifying antirheumatic drugs (DMARDs), cytotoxic agents, cytokine antagonists or monoclonal antibodies, tofacitinib, glucocorticoids, etc. [1-3]. These therapies generally control RA disease activity by either suppressing overall immune function or partially neutralizing individual cytokines or partially antagonizing individual cytokine receptors; however, they rarely modulate immune cell populations, except for methotrexate (MTX) [4-8]. Furthermore, they not only cannot cure the disease but also inadequately discontinue disease progression, especially for the invasive destruction of articular cartilage and bone. In particular, they can also increase the potential risk of severe infections and malignancy $[4,5]$.

Unlike current aforementioned therapies, antigen-specific tolerizing DNA vaccine pcDNA-CCOL2A1 encoding chicken type II collagen exerts its therapeutic effects through specific immune modulation, especially for inducing potent immune tolerance against RA. More precise mechanisms of action include increase in the contents of $\mathrm{CD} 4{ }^{+} \mathrm{CD} 25^{+} \mathrm{T}$ regulatory cells, reductions in the specific proliferative response of $\mathrm{T}$ lymphocytes to $\mathrm{CII}$, and induction of a shift from Th1 to Th2 cells, accompanied by down-regulation of Th1-cytokine TNF- $\alpha$ and up-regulation of both Th2-cytokine IL10 and Th3-cytokine TGF- $\beta$. Moreover, we previously reported that DNA vaccine pcDNA-CCOL2A1 displayed efficacy comparable to those of the current "gold standard" therapy, methotrexate (MTX), in the established collagen-induced arthritis (CIA) rat model. And it is safe and well-tolerated without any abnormal clinical signs and adverse effects on normal physiological function [9-12], suggesting that this vaccine has a high drugability.

Successful establishment of a three-tier cell bank with high stability and identification of a high-yield Escherichia coli $\mathrm{DH} 5 \alpha$ strain to produce therapeutic DNA vaccine pcDNA-CCOL2A1 would yield a sound theoretical and material basis for further pilot-scale tests and even industrial-scale production of this vaccine [13]. Furthermore, fermentation conditions including growth conditions, culture types, and culture medium composition influence the yield and productivity of plasmid DNA vaccines, by directly influencing the downstream purification, quality and yield of plasmid DNA vaccines [14-16]. Since many factors existed in the fermentation condition, a great number of experiments should be simultaneously conducted, and the possible interactions between these factors would be studied. So a reasonable analytical methods will lead to lower reagent consumption and considerably less laboratory work. Conventional single dimensional research gives unreliable results, inaccurate conclusion. Orthogonal testing optimum design can reduce the number of combinations, and obtain optimal factor levels. However, it cannot give a regression equation for the whole parameter tested. By contrast, the combination of Plackett-Burman design (PBD) with common optimization methodology Box-Behnken design-response surface method (BBD-RSM) can collectively eliminate these limitations and are powerful and useful in determining the key factors rapidly from a multivariable system [17]. PBD provides indication and tendency regarding the necessity of each variables in relatively few experiments, the following Box-Behnken design (BBD) provides a large amount of information and the interaction of the independent variables on the response by a small number of experiment [18-21]. The data from $\mathrm{BBD}$ subject to a second-order multiple regression equation showing the dependence of the response (i.e. the plasmid yield) on independent variables (i.e. the concentration of the separate components of the nutrient medium or fermentation parameters), and even give predictive results of responses and the possible levels of related independent variables. The equation of the model can clearly present the effects for binary combinations of the independent variables.

Essentially, plasmid DNA vaccine production is aimed at increasing yield and productivity and decreasing manufacturing cost. Hence, we hypothesize that optimization of fermentation conditions significantly increases the yield and productivity of therapeutic DNA vaccine pcDNA-CCOL2A1. The present study aimed to determine the effect of optimized fermentation conditionsof the engineered Escherichia coli $\mathrm{DH} 5 \alpha$ on the yield of therapeutic DNA vaccine pcDNA-CCOL2A1. To our knowledge, this is the first study to systemically optimize fermentation conditions of the engineered Escherichia coli DH5 $\alpha$ for producing therapeutic DNA vaccine pcDNA-CCOL2A1 through a combination of the commonly used $\mathrm{PBD}$ with common optimization methodology BBD-RSM.

\section{Results \\ Single-factor analysis of basal culture medium revealed optimal carbon and nitrogen sources for producing therapeutic DNA vaccine PcDNA-CCOL2A1}

Several previous studies have reported the precedence of single-factor analysis before using PBD and BBD [22, 23]. Accordingly, initial screening was performed for the selection of optimum basal culture medium, wherein $2 \times \mathrm{YT}$ was found to be advantageous for the yield of plasmid DNA vaccine pcDNA-CCOL2A1 produced by the engineered E. coli DH5 $\alpha$. Further evaluation of carbon and nitrogen sources indicated that mannitol and peptone can significantly increase plasmid yield compared with the basal culture medium $2 \times$ YT $(p<0.05)$, as shown in Fig. 1a-b. 

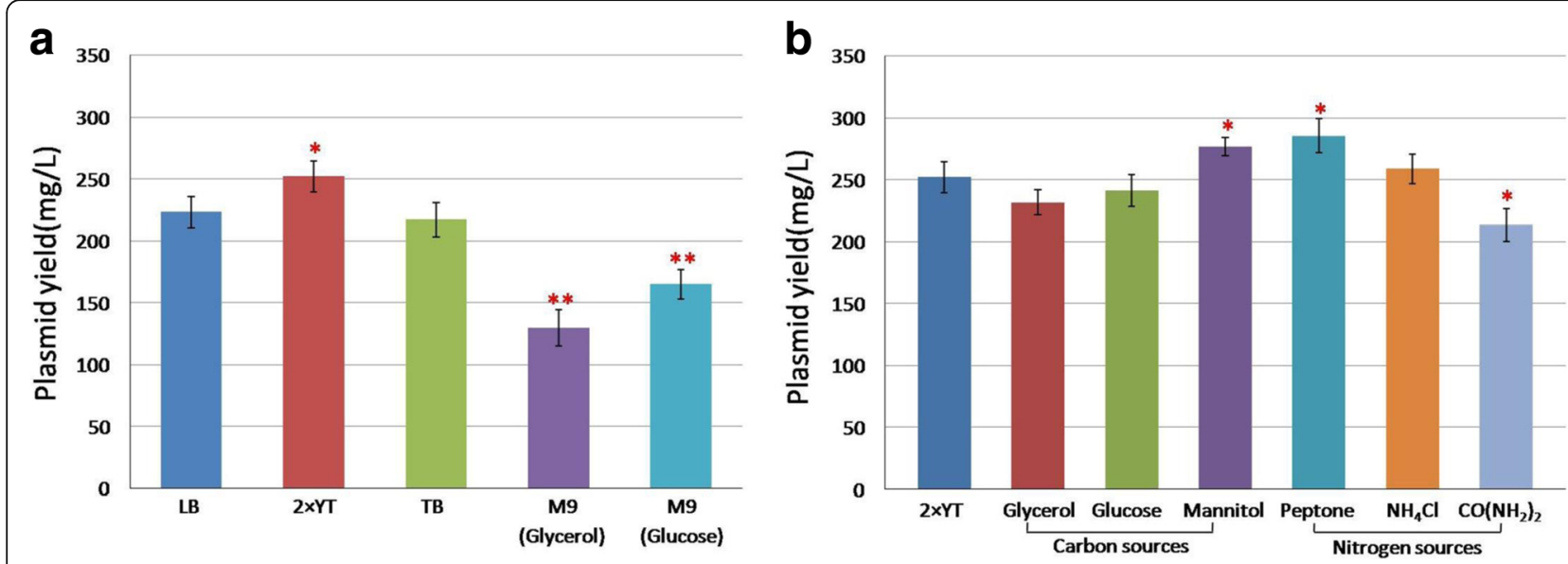

Fig. 1 a, b Single-factor analysis of basal culture medium revealed optimal carbon and nitrogen sources for producing therapeutic DNA vaccine pCDNA-CCOL2A1. a Evaluation of the optimal basal culture medium among LB, $2 \times Y T$, TB, M9 (Glycerol) and M9 (Glucose) in shaking flask culture through One-Way ANOVA. b Screen the optimal carbon and nitrogen sources in shaking flask culture using One-Way ANOVA. ${ }^{*} p<0.05,{ }^{*}{ }^{*} p<0.001$. Data are expressed as the mean \pm standard deviation (SD) of 3 independent experiments

PBD screening elucidated the key variables affecting the yield of therapeutic DNA vaccine pcDNA-CCOL2A1

In the PBD experiment, ten variables were chosen to screen the key factors affecting the yield of plasmid DNA vaccine, as shown in Table 1. The data reported in Table 2 showed a substantial variation in plasmid yield among the 12 experimental sets, varying from $146.60 \pm 15.25 \mathrm{mg} / \mathrm{L}$ to $312.86 \pm 13.69 \mathrm{mg} / \mathrm{L}$ under two different levels of factors. Based on regression analysis of PBD in Table 3, the fitting model for the yield of plasmid DNA vaccine was significant $(p=0.0287)$. The ratio of adequate precision measures the signal-to-noise ratio, and a ratio greater than 4 is desirable. In this case, adequate precision was 84.831, confirming that the model could adequately navigate the design space.

Table 1 Variables and their levels used in Plackett-Burman design for screening of culture conditions affecting the yield of plasmid DNA vaccine PCDNA-CCOL2A1 by the engineered E. coli DH5a

\begin{tabular}{llll}
\hline $\begin{array}{l}\text { Symbol } \\
\text { code }\end{array}$ & Factors & \multicolumn{2}{l}{ Experimental values } \\
\cline { 3 - 4 } & & Low level $(-1)$ & High level $(+1)$ \\
\hline $\mathrm{A}(\mathrm{g} / \mathrm{L})$ & Peptone & 16.00 & 24.00 \\
$\mathrm{~B}(\mathrm{~g} / \mathrm{L})$ & Yeast extract & 10.00 & 15.00 \\
$\mathrm{C}(\mathrm{g} / \mathrm{L})$ & $\mathrm{NaCl}$ & 5.00 & 7.50 \\
$\mathrm{D}(\mathrm{g} / \mathrm{L})$ & Ampicilin & 0.05 & 0.10 \\
$\mathrm{E}(\mathrm{mL} / \mathrm{L})$ & Microelement & 10.00 & 15.00 \\
$\mathrm{~F}(\mathrm{~g} / \mathrm{L})$ & Mannitol & 5.00 & 7.50 \\
$\mathrm{G}$ & Initial pH & 6.00 & 8.00 \\
$\mathrm{H}(\mathrm{RPM})$ & Rotational speed & 180 & 250 \\
$\mathrm{~J}\left({ }^{\circ} \mathrm{C}\right)$ & Temperature & 30.00 & 37.00 \\
$\mathrm{~K}(\mathrm{OD})$ & Inoculum concentration & 0.10 & 0.20 \\
$\mathrm{~L}$ & Dummy factors & & \\
\hline
\end{tabular}

The goodness of the model was checked by the determination coefficient $\mathrm{R}^{2}$, which was 0.9999. Among these factors, peptone, yeast extract, mannitol, and inoculum concentration were the significant model terms on the response $(p<0.05)$. The three most significant variables were peptone, mannitol, and inoculum concentration, and their contributions to the yield of plasmid DNA vaccine were $48.18 \%, 21.56 \%$, and $21.55 \%$ respectively. In particular, these three variables exerted a positive effect on plasmid production. Other independent variables with $p>0.05$ were generally considered insignificant and would be not included in the subsequent optimizing step. Thereafter, the culture conditions were reduced to three most significant variables: peptone, mannitol, and inoculums concentration. The precise optimal values of the individual variables were still unknown but could be determined through subsequent BBD.

\section{The steepest ascent experiment optimized the key variables affecting the yield of therapeutic DNA vaccine pcDNA-CCOL2A1}

Based on the analysis of the screening design, the path of steepest ascent was then applied to determine the most suitable direction for changing the variable ranges. As the three most significant variables exerted a positive effect on plasmid production, the direction of steepest ascent should increase their concentration to approach the optimal experimental region of maximum response. Five sets of experiments of the steepest ascent and corresponding experimental results were showed in Table 4. The yield of plasmid DNA vaccine peaked at the third step and no further improvement could be achieved in there sponse when peptone, mannitol, and inoculum 
Table 2 Plackett-Burman design matrix with response value for screening of culture conditions affecting the yield of plasmid DNA vaccine pcDNA-CCOL2A1 by the engineered E. coli DH5a

\begin{tabular}{|c|c|c|c|c|c|c|c|c|c|c|c|c|}
\hline \multirow[t]{2}{*}{ Run } & \multicolumn{11}{|c|}{ Variable levels } & \multirow{2}{*}{$\begin{array}{l}\text { Plasmid yield } \\
(\mathrm{mg} / \mathrm{L})\end{array}$} \\
\hline & A & $B$ & $C$ & $\mathrm{D}$ & E & $\mathrm{F}$ & G & $\mathrm{H}$ & J & K & $\mathrm{L}$ & \\
\hline 1 & 1 & -1 & 1 & 1 & -1 & 1 & 1 & 1 & -1 & -1 & -1 & $258.29 \pm 6.44$ \\
\hline 2 & -1 & 1 & 1 & -1 & 1 & 1 & 1 & -1 & -1 & -1 & 1 & $202.98 \pm 7.37$ \\
\hline 3 & 1 & -1 & -1 & -1 & 1 & -1 & 1 & 1 & -1 & 1 & 1 & $267.36 \pm 11.00$ \\
\hline 4 & -1 & -1 & -1 & -1 & -1 & -1 & -1 & -1 & -1 & -1 & -1 & $158.51 \pm 11.30$ \\
\hline 5 & -1 & -1 & -1 & 1 & -1 & 1 & 1 & -1 & 1 & 1 & 1 & $234.83 \pm 14.17$ \\
\hline 6 & 1 & 1 & 1 & -1 & -1 & -1 & 1 & -1 & 1 & 1 & -1 & $279.81 \pm 10.27$ \\
\hline 7 & 1 & 1 & -1 & 1 & 1 & 1 & -1 & -1 & -1 & 1 & -1 & $312.86 \pm 13.69$ \\
\hline 8 & -1 & 1 & 1 & 1 & -1 & -1 & -1 & 1 & -1 & 1 & 1 & $198.70 \pm 11.36$ \\
\hline 9 & -1 & -1 & 1 & -1 & 1 & 1 & -1 & 1 & 1 & 1 & -1 & $220.79 \pm 8.51$ \\
\hline 10 & 1 & 1 & -1 & -1 & -1 & 1 & -1 & 1 & 1 & -1 & 1 & $284.63 \pm 10.09$ \\
\hline 11 & -1 & 1 & -1 & 1 & 1 & -1 & 1 & 1 & 1 & -1 & -1 & $146.60 \pm 15.25$ \\
\hline 12 & 1 & -1 & 1 & 1 & 1 & -1 & -1 & -1 & 1 & -1 & 1 & $181.27 \pm 10.67$ \\
\hline
\end{tabular}

Data are expressed as the mean \pm standard deviation (SD) of 3 batches independent experiments for each strain

concentration were selected to be $26 \mathrm{~g} / \mathrm{L}, 8 \mathrm{~g} / \mathrm{L}$ and 0.35 , respectively, which suggested that it was proximal to the region of maximum response. Accordingly, these levels of the three factors in the third set were considered the center point of BBD.

\section{BBD optimized the screened culture conditions for} the yield of therapeutic DNA vaccine pcDNA-CCOL2A1 Preliminary trials confirmed that peptone (24-28 g/L), mannitol (7 9 g/L), and inoculum concentration (0.25 0.45) were suitable. In the present analysis, experiments were designed to obtain a second-order polynomial equation consisting of 12 trials plus 5 central points. The design matrix of the variables was showed in Table 5 along with the experimental values of response. Through multiple regression analysis of the experimental data, shown in Table 5, the following second-orderpolynomial equation was derived for the plasmid yield by only considering the significant terms:

$$
\begin{aligned}
Y & =338.78-3.70 \times \mathrm{A}+5.06 \times \mathrm{B}+3.98 \times \mathrm{C} \\
& +10.52 \times \mathrm{A} \times \mathrm{B}+3.18 \times \mathrm{A} \times \mathrm{C}-5.98 \times \mathrm{B} \\
& \times \mathrm{C}-18.12 \times \mathrm{A}^{2}-23.34 \times \mathrm{B}^{2}-15.89 \times \mathrm{C}^{2}
\end{aligned}
$$

Where $\mathrm{Y}$ is the predicted response of plasmid yield, $\mathrm{A}$, $\mathrm{B}$, and $\mathrm{C}$ are the coded values of peptone, mannitol, and inoculum concentration, respectively. Statistical significance of the second-order model and all the coefficient estimates were assessed using ANOVA, and the data are shown in Table 6. The quadratic regression model was highly significant, which was evident from the F-test with a very low probability value $(p<0.0001)$. The value

\begin{tabular}{|c|c|c|c|c|c|}
\hline Code & Term & Stdized Effects & \%Contribution & F-Value & $p$-Value \\
\hline & Model & & & 734.21 & 0.0287 \\
\hline A & Peptone(g/L) & 70.30 & 48.18 & 3538.00 & $0.0107^{*}$ \\
\hline B & Yeast extract(g/L) & 17.42 & 2.96 & 217.36 & $0.0431^{*}$ \\
\hline C & $\mathrm{NaCl}(\mathrm{g} / \mathrm{L})$ & -10.49 & 1.07 & 78.81 & 0.0714 \\
\hline D & $A m p(g / L)$ & -13.59 & 1.80 & 132.16 & 0.0552 \\
\hline$E$ & Microelement $(\mathrm{mL} / \mathrm{L})$ & -13.82 & 1.86 & 136.70 & 0.0543 \\
\hline$F$ & Mannitol(g/L) & 47.02 & 21.56 & 1582.96 & $0.0160^{*}$ \\
\hline G & Initial pH & 5.52 & 0.30 & 21.79 & 0.1344 \\
\hline $\mathrm{H}$ & Rotational speed(RPM) & 1.02 & 0.010 & 0.74 & 0.5470 \\
\hline J & Temperature $\left({ }^{\circ} \mathrm{C}\right)$ & -8.46 & 0.70 & 51.27 & 0.0883 \\
\hline K & Inoculum concentration(OD) & 47.01 & 21.55 & 1582.33 & $0.0160^{*}$ \\
\hline
\end{tabular}
of adj- $R^{2}(0.9626)$ suggested that the total variation of

Table 3 The regression analysis of variance for Plackett-Burman factorial model for the yield of plasmid DNA vaccine 
Table 4 Steepest ascent experiments to move the experimental region towards the maximum yield of plasmid DNA vaccine pCDNA-CCOL2A1 by the engineered E. coli DH5a

\begin{tabular}{lllll}
\hline Run & Peptone(g/L) & $\begin{array}{l}\text { Mannitol } \\
(\mathrm{g} / \mathrm{L})\end{array}$ & $\begin{array}{l}\text { Inoculum concentration } \\
(\mathrm{OD})\end{array}$ & $\begin{array}{l}\text { Plasmid yield } \\
(\mathrm{mg} / \mathrm{L})\end{array}$ \\
\hline 1 & 22 & 6 & 0.15 & $296.92 \pm 10.00$ \\
2 & 24 & 7 & 0.25 & $313.76 \pm 8.01$ \\
3 & 26 & 8 & 0.35 & $338.57 \pm 11.92$ \\
4 & 28 & 9 & 0.45 & $326.04 \pm 8.65$ \\
5 & 30 & 10 & 0.55 & $303.95 \pm 8.46$ \\
\hline
\end{tabular}

Data are expressed as the mean \pm standard deviation (SD) of 3 batches independent experiments for each strain

96.26\% for the yield of plasmid DNA vaccine was attributed to the independent variables. The determination coefficient $\left(R^{2}=0.9836\right)$, which is commonly used to assess the goodness of the model, exhibited an excellent correlation between the experimental and predicted response values. Alow CV $(\mathrm{CV}=1.25 \%)$ value clearly revealed that the deviations between experimental and predicted values were low and it displayed not only a high degree of precision but also high reliability in conducted experiments. Adequate precision measures the signal-to-noise ratio, and a ratio greater than 4 is desirable. In this study, a ratio of 20.387 indicated an adequate signal. Therefore, the quadratic model was selected in this optimization study. Table 6 showed the corresponding $p$-value and the parameter estimate.
This multiple nonlinear model resulted in three response surface graphs through canonical analysis of the response surface. Interpretation of the response surface 3D model and contour plot were the graphical representations of regression equation. They provided visual interpretations of the relationship between responses and experimental levels of each variable, and the type of interactions between two test variables. Fig. 2a was the fitted response surface 3D model and their corresponding contour plots for the yield of plasmid DNA vaccine produced by the predicted model, respectively. Fig. 1a shows that the yield of plasmid DNA vaccine significantly increased with peptone increasing from 24 to $25.86 \mathrm{~g} / \mathrm{L}$, mannitol increasing from 7 to $8.08 \mathrm{~g} / \mathrm{L}$, but decreased beyond this centerpoint, reaching a maximum yield of $339.03 \mathrm{mg} / \mathrm{L}$. The effect of peptone and mannitolon the yield of plasmid DNA vaccine was also sensitive within the tested range, which was proved by the $p$-value $(0.0309,0.0078)$ in Table 6 . Furthermore, the significant interaction of peptone and mannitol could be easily explained by its elliptical shape of the contour plot and $p$-value (0.001). It was also noticed in Fig. 2b-c that the response presented downward movement when the value of variables was higher than the center point, indicating the existence of the maximum predicted value of the yield of plasmid DNA vaccine. The statistical optimal values of variables were obtained when moving along the major and minor axes of the contour and the response at

Table 5 Through BBD optimizing the screened culture conditions for the yield of plasmid DNA vaccine pcDNA-CCOL2A1 by the engineered Escherichia coli DH5a

\begin{tabular}{|c|c|c|c|c|c|c|c|}
\hline \multirow[t]{2}{*}{ Run } & \multicolumn{2}{|c|}{ A-Peptone(g/L) } & \multicolumn{2}{|c|}{ B-Mannitol(g/L) } & \multicolumn{2}{|c|}{ C-Inoculum concentration(OD) } & \multirow{2}{*}{$\begin{array}{l}\text { Plasmid yield } \\
\text { (mg/L) }\end{array}$} \\
\hline & Code level & Real level & Code level & Real level & Code level & Real level & \\
\hline 1 & 1 & 28 & -1 & 7 & 0 & 0.35 & $277.80 \pm 8.38$ \\
\hline 2 & 1 & 28 & 0 & 8 & -1 & 0.25 & $293.63 \pm 5.63$ \\
\hline 3 & 1 & 28 & 0 & 8 & 1 & 0.45 & $307.20 \pm 6.81$ \\
\hline 4 & 0 & 26 & -1 & 7 & 1 & 0.45 & $305.73 \pm 9.32$ \\
\hline 5 & 0 & 26 & 1 & 9 & -1 & 0.25 & $305.33 \pm 11.90$ \\
\hline 6 & 0 & 26 & 0 & 8 & 0 & 0.35 & $332.53 \pm 14.61$ \\
\hline 7 & 0 & 26 & 0 & 8 & 0 & 0.35 & $335.60 \pm 10.52$ \\
\hline 8 & 0 & 26 & 0 & 8 & 0 & 0.35 & $339.70 \pm 10.91$ \\
\hline 9 & 0 & 26 & 0 & 8 & 0 & 0.35 & $345.10 \pm 13.60$ \\
\hline 10 & 0 & 26 & -1 & 7 & -1 & 0.25 & $285.03 \pm 8.23$ \\
\hline 11 & -1 & 24 & 0 & 8 & 1 & 0.45 & $309.53 \pm 9.69$ \\
\hline 12 & -1 & 24 & 0 & 8 & -1 & 0.25 & $308.70 \pm 10.68$ \\
\hline 13 & -1 & 24 & 1 & 9 & 0 & 0.35 & $295.80 \pm 10.61$ \\
\hline 14 & 0 & 26 & 1 & 9 & 1 & 0.45 & $302.10 \pm 14.45$ \\
\hline 15 & 1 & 28 & 1 & 9 & 0 & 0.35 & $310.73 \pm 10.71$ \\
\hline 16 & 0 & 26 & 0 & 8 & 0 & 0.35 & $340.97 \pm 13.16$ \\
\hline 17 & -1 & 24 & -1 & 7 & 0 & 0.35 & $304.93 \pm 8.88$ \\
\hline
\end{tabular}

Data are expressed as the mean \pm standard deviation (SD) of 3 batches independent experiments for each strain 
Table 6 Regression analysis of a full second-order polynomial model for the optimized yield of plasmid DNA vaccine by the engineered E. coli DH5a

\begin{tabular}{clllll}
\hline Term & Sum of Squares & df & Mean Square & $F$-Value & $p$-value \\
\hline Model & 6344.09 & 9 & 704.90 & 46.72 & $<0.0001^{*}$ \\
A & 109.52 & 1 & 109.52 & 7.26 & $0.0309^{*}$ \\
B & 204.70 & 1 & 204.70 & 13.57 & $0.0078^{*}$ \\
C & 126.94 & 1 & 126.94 & 8.41 & $0.0230^{*}$ \\
AB & 442.39 & 1 & 442.39 & 29.32 & $0.0010^{*}$ \\
AC & 40.54 & 1 & 40.54 & 2.69 & 0.1452 \\
BC & 143.20 & 1 & 143.20 & 9.49 & $0.0178^{*}$ \\
$A^{2}$ & 1382.96 & 1 & 1382.96 & 91.65 & $<0.0001^{*}$ \\
$B^{2}$ & 2293.73 & 1 & 2293.73 & 152.01 & $<0.0001^{*}$ \\
$C^{2}$ & 1063.13 & 1 & 1063.13 & 70.46 & $<0.0001^{*}$ \\
Residual & 105.62 & 7 & 15.09 & & \\
Lack of fit & 10.92 & 3 & 3.64 & 0.15 & 0.9221 \\
Pure Error & 94.71 & 4 & 23.68 & & \\
Cor Total & 6449.71 & 16 & & & \\
\hline
\end{tabular}

$R^{2}=0.9836$, adj $-R^{2}=0.9626$, Adequate precision $=20.387, C V=1.25 \%$, Adequate precision $=20.387$

*Identified variables with a significant effect on the response $(p$-value $<0.05)$

the center point yields the maximum plasmid production. These observations were also verified through canonical analysis of the response surface. By solving the inverse matrix from the second-order polynomial equation, the optimum values of the test variables were peptone, $25.86 \mathrm{~g} / \mathrm{L} ; \mathrm{mannitol}, 8.08 \mathrm{~g} / \mathrm{L}$; inoculum concentration, 0.36 . Under the optimal conditions, the maximum predicted the yield of plasmid DNA vaccine was $339.32 \mathrm{mg} / \mathrm{L}$. To confirm the validity of the model for predicting the maximum yield of plasmid DNA vaccine, an additional experiment using this optimum operation conditions was performed under shake-flask culture. The average yield of plasmid DNA vaccine was $341.86 \pm 10.67 \mathrm{mg} / \mathrm{L}(N=3)$. The results were closely related to the data obtained from optimization analysis, suggesting that the RSM model was adequate for reflecting the expected optimization, and the model was satisfactory and accurate.

\section{Discussion}

The final acquisition of plasmid DNA vaccines with the highest yield, purity, and quality were closely related to not only the upstream antigen-specific genes for disease targets, the most appropriate expression vectors, and the appropriate Escherichia coli strains for production, but also the optimized fermentation conditions, culture media, and scale-up as well as the downstream purification technology [24-30]. In the present study, we have optimized the fermentation conditions at a shake-flask level for the engineered Escherichia coli DH5 $\alpha$ to for high yield of therapeutic DNA vaccine pcDNA-CCOL2A1 through combined PBD with BBD-RSM, by which the yield of therapeutic DNA vaccine pcDNA-CCOL2A1 was markedly increased.

In practice terms, the medium compositions such as the basal culture media, the carbon sources, the nitrogen sources, the carbon/nitrogen ratio $(\mathrm{C} / \mathrm{N})$, amino acid starvation, etc., as the essential factors for the fermentation conditionsfor the production of plasmid DNA vaccines are usually the first to be chosen and optimized in the beginning of the fermentation condition optimization for increasing plasmid DNA production in E. coli strains $[14,15]$. The fermentation condition optimization, including screening of optimal medium compositions, is influenced by many factors, among which, interactions may exist. The routine single-dimensional studies changing one independent variable at a time and maintaining the others constant yields unreliable results, inaccurate conclusions, and even frequent interactions of two or more factors [17]. Thus, it is necessary to apply reasonable experimental designs and optimization methodologies in condition screening and process optimization. Because E. coli strain DH5a used in the present study was selected typically for plasmid DNA production [31], we first used single-factor analysis to evaluate several basal culture media commonly used for culturing DH5a, which include LB, $2 \times$ YT, TB, M9 (Glycerol) and M9 (Glucose). Finally, we screened $2 \times$ YT as the optimal basal culture medium, mannitol as the optimal carbon source, and peptone as the optimal nitrogen source. In theory, the production of plasmid DNA vaccines is also affected by varying both carbon and nitrogen concentrations [30, 32-34]. Thus, we applied PBD to further screen out the three most significant factors affecting the yield of therapeutic DNA vaccine pcDNA-CCOL2A1, followed by the paths of steepest ascent to move to the nearest region of maximum response. The most significant factors identified through PBD were peptone, mannitol, and inoculum concentrations. Together, our results indicate that PBD is efficient in screening medium components at the shake-flask level and has been widely used in the optimization of fermentation conditions $[18,19]$. This technique cannot determine the exact quantity but can provide indication and tendency regarding the necessity of each variables in relatively few experiments.

In the present study, we used RSM to further optimize the yield of therapeutic DNA vaccine pcDNA-CCOL2A1 by BBD. RSM not only helped locate the optimum levels of the most significant factors but also proved to be useful and satisfactory in this process-optimizing practice. Through these optimization experiments, the maximum yield of plasmid DNA vaccine at $339.32 \mathrm{mg} / \mathrm{L}$ was obtained under the optimum conditions with peptone (25.86 g/L), mannitol (8.08 g/L), and inoculum concentration $(\mathrm{OD}=0.36)$, which is significantly higher than 

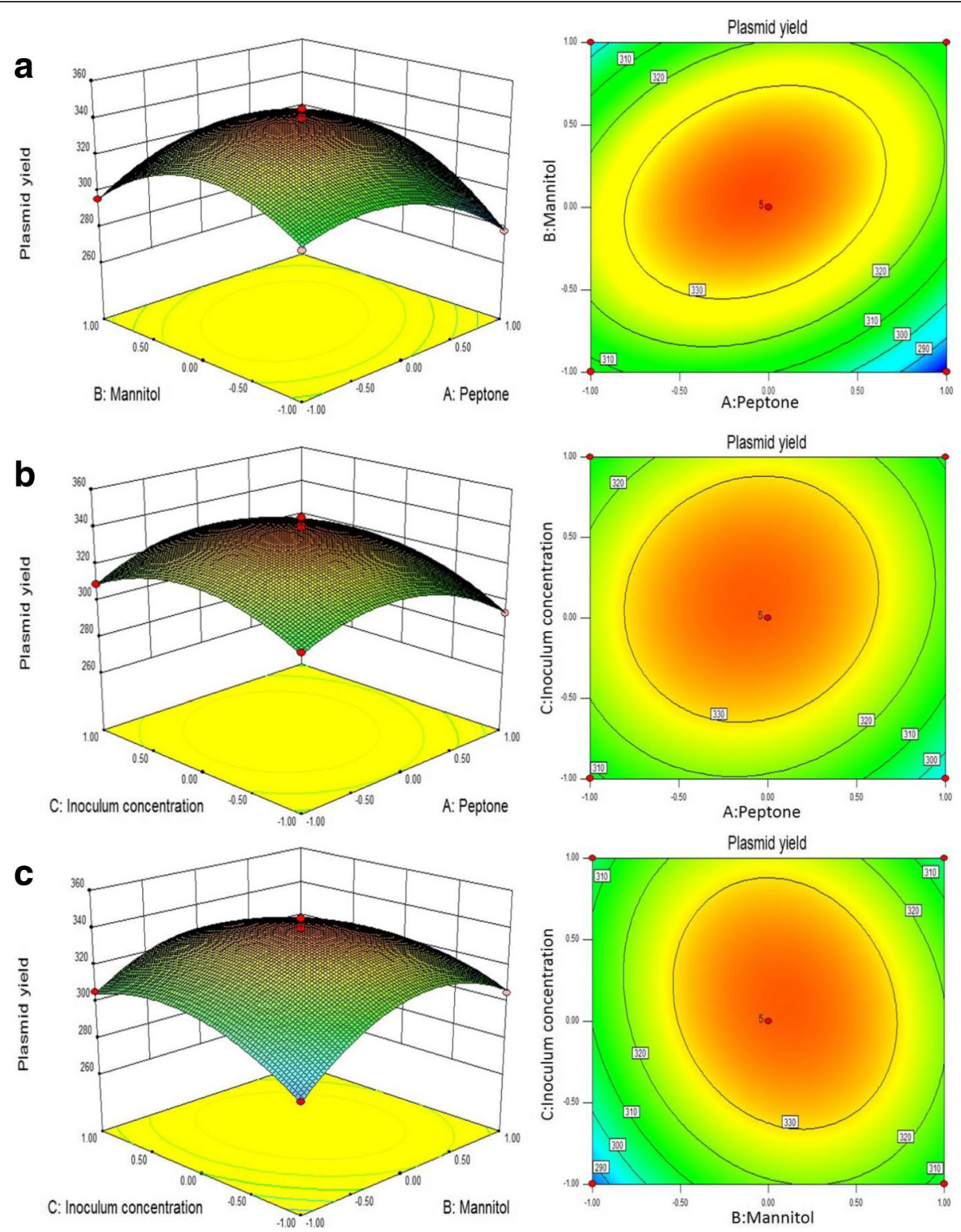

Fig. 2 a, b, c Response surface 3D model (left) and contour plot (right) to assessthe effects of the three variables on the yield of plasmid DNA vaccine pcDNA-CCOL2A1 produced by the engineered E. coli DH5a. a response surface plot showing the mutual effect of peptone and mannitol on the yield of plasmid DNA vaccine PCDNA-CCOL2A1; $\mathbf{b}$ response surface plot showing the mutual effect of peptone and inoculum concentration on the yield of plasmid DNA vaccine pCDNA-CCOL2A1; c response surface plot showing the mutual effect of mannitol and inoculum concentration on the yield of plasmid DNA vaccine pCDNA-CCOL2A1

those of most studies. Most current fermentation media and processes have only resulted in low yields of plasmid DNA $(<200 \mathrm{mg} / \mathrm{L})[14,35]$, though a few have resulted in high yields (500-1500 mg/L) [36-38]. Compared with the original medium, an increase of $51.9 \%$ was obtained. The predicted plasmid yield was closely related with the experimental value, which was $341.86 \pm 10.67 \mathrm{mg} / \mathrm{L}$ $(N=3)$. Further studies are required to assess the optimization of fermentation conditions involving in several major factors such as growth conditions, culture types, culture medium compositions, etc. In the present study, we obtained a higher yield of plasmid DNA vaccine by only optimizing the two factors of the components of the nutrient medium and inoculum concentration. Hence, further optimization of fermentation conditions including growth conditions and culture types would significantly increase both the yield and productivity of therapeutic DNA vaccine pcDNA-CCOL2A1. These optimization methods for fermentation conditions are currently being investigated in our laboratory. 


\section{Conclusions}

In summary, the fermentation medium and conditions of the engineered Escherichia coli $\mathrm{DH} 5 \alpha$ producing a novel therapeutic DNA vaccine pcDNA-CCOL2A1 were scientifically selected and optimized by RSM. Under the optimum conditions with peptone $(25.86 \mathrm{~g} / \mathrm{L})$, mannitol $(8.08 \mathrm{~g} / \mathrm{L})$, and inoculum concentration $(\mathrm{OD}=0.36)$, the maximum yield of plasmid DNA vaccine at $339.32 \mathrm{mg} / \mathrm{L}$ was obtained, with an increase of $51.9 \%$. In addition to this, we conducted experiments under the optimal conditions. The experimental value was $341.86 \pm 10.67 \mathrm{mg} / \mathrm{L}(N=3)$, which was closely related with the predicted plasmid yield. The present results will provide a robust foundation for further pilot-scale tests and industrial-scale production of final high-quality and high-yield therapeutic DNA vaccine pcDNA-CCOL2A1 for RA in the near future.

\section{Methods}

\section{Plasmid and bacterial strains}

Eukaryotic expression vector for producing therapeutic DNA vaccine pcDNA-CCOL2A1 was previously constructed in our laboratory, which contains a 4837 bp cDNA sequence encoding the chicken type II procollagen gene, but lacking the N-propeptides. To obtain high levels of CCOL2A1 gene expression, both the signal sequence and the Kozak consensus sequence were inserted into pcDNA $^{\mathrm{ma}} 3.1(+)$, a highly stable vector used for transient gene expression $[9,39]$. The resulting recombinant plasmid containing an ampicillin resistance gene for selection was cloned in E. coli DH5 a (CB101; Tiangen, Beijing, China).

\section{Medium and cultivation}

Media included Luria-Bertani (LB) [10 g/L tryptone, $5 \mathrm{~g} /$ $\mathrm{L}$ yeast extract, $10 \mathrm{~g} / \mathrm{L} \mathrm{NaCl}, \mathrm{pH}$ 7.0], Tartof and Hobbs (TB) $[12 \mathrm{~g} / \mathrm{L}$ tryptone, $24 \mathrm{~g} / \mathrm{L}$ yeast extract, $0.4 \%$ glycerol, $\left.2.31 \mathrm{~g} / \mathrm{L} \quad \mathrm{KH}_{2} \mathrm{PO}_{4}, 12.54 \mathrm{~g} / \mathrm{L}_{2} \mathrm{~K}_{2} \mathrm{HPO}_{4}\right]$, M9 [0.01 g/L $\mathrm{CaCl}_{2}, 0.24 \mathrm{~g} / \mathrm{L} \mathrm{MgSO} 4,12.8 \mathrm{~g} / \mathrm{L} \mathrm{Na}_{2} \mathrm{HPO}_{4} \cdot 7 \mathrm{H}_{2} \mathrm{O}, 3 \mathrm{~g} / \mathrm{L}$ $\mathrm{KH}_{2} \mathrm{PO}_{4}, 0.5 \mathrm{~g} / \mathrm{L} \mathrm{NaCl}, 1 \mathrm{~g} / \mathrm{L} \mathrm{NH} \mathrm{NH}_{4} \mathrm{Cl}, 20 \%$ Glucose or Glycerol], $2 \times \mathrm{YT}$ [16 g/L tryptone, $10 \mathrm{~g} / \mathrm{L}$ yeast extract, $5 \mathrm{~g} / \mathrm{L} \mathrm{NaCl}, \mathrm{pH}$ 7.0], and Microelement mix [0.01 g/L $\mathrm{MnSO}_{4} \cdot 7 \mathrm{H}_{2} \mathrm{O}, 0.05 \mathrm{~g} / \mathrm{L} \mathrm{ZnSO} \cdot \cdot 7 \mathrm{H}_{2} \mathrm{O}, 0.01 \mathrm{~g} / \mathrm{L} \mathrm{H}_{3} \mathrm{BO}_{3}$, $0.01 \mathrm{~g} / \mathrm{L} \quad \mathrm{CaCl}_{2} \cdot 2 \mathrm{H}_{2} \mathrm{O}, \quad 0.01 \mathrm{~g} / \mathrm{L} \quad \mathrm{Na}_{2} \mathrm{MoO}_{4}, \quad 0.2 \mathrm{~g} / \mathrm{L}$ $\mathrm{CoCl}_{2} \cdot 6 \mathrm{H}_{2} \mathrm{O}, \quad 0.01 \mathrm{~g} / \mathrm{L} \quad \mathrm{AlK}\left(\mathrm{SO}_{4}\right)_{2} \cdot 12 \mathrm{H}_{2} \mathrm{O}, 0.001 \mathrm{~g} / \mathrm{L}$ $\mathrm{NiCl}_{2} \cdot 6 \mathrm{H}_{2} \mathrm{O}$ ] [40]. Engineered Escherichia coli DH5 $\alpha$ were cultured in $100 \mathrm{~mL}$ of medium in $500 \mathrm{~mL}$ Erlenmeyer flasks with the initial inoculum concentration of $\mathrm{OD}_{600}=0.1$, and incubated at $37{ }^{\circ} \mathrm{C}$ on a rotary shaker at $220 \mathrm{rpm}$. After $16 \mathrm{~h}$ of incubation, plasmid DNA was purified from the bacterial cell, using the Wizard ${ }^{\mathrm{R}}$ Plus SV Minipreps DNA Purification System (Promega, USA). The concentrations of the plasmid pcDNA-CCOL2A1 were measured at $\mathrm{OD}_{260}$ and $\mathrm{OD}_{280}$ using Synergy ${ }^{\mathrm{Tm}} \mathrm{HT}$ Multi-Mode Microplate Reader (BioTek Instruments, Inc., Winooski, VT, USA).

\section{Single-factor analysis}

In each experiment, one factor was changed with the other factors remaining constant. The initial evaluation was performed to identify the optimal basal culture medium from LB, $2 \times$ YT, TB, M9 (glycerol) and M9 (glucose). The effect of various carbon and nitrogen sources was also determined through single-factor analysis. Carbon sources (5 g/L glycerol, glucose, and mannitol) were evaluated, while other components were maintained constant as basal culture medium. The nitrogen sources ( $5 \mathrm{~g} / \mathrm{L}$ peptone, $\mathrm{NH}_{4} \mathrm{Cl}$, urea) were analyzed with other constituents as that of basal culture medium. Although this method is time-consuming, it is propitious to the selection of level in $\mathrm{PBD}$, rendering the results more reasonable and credible.

\section{Plackett-Burman design for screening}

Multiple regression analysis and analysis of variance (ANOVA) were conducted for fitting the mathematical model using Design Expert software (Version 8.0.6, Stat-Ease Inc., Minneapolis, MN, USA). Ten variables (peptone, yeast extract, $\mathrm{NaCl}$, Ampicillin [Amp], microelements, mannitol, rotational speed, $\mathrm{pH}$, fermentation temperature, and inoculum concentration) were assessed using PBD and the model was evaluated using the F-test and goodness of fit through multiple correlations R. Each independent variable was tested at two levels, high and low, which are denoted by $(+)$ and $(-)$, respectively. The experimental design with the name, symbol code, and actual levels of the variables are shown in Tables 1 and 2 shows details of the design matrix. In this study, 12 experiments were conducted and the most optimal variables were selected for further evaluation. Based on regression analysis of the variables, significant levels at 95\% level $(p<0.05)$ were considered to significantly affect the yield of the plasmid vaccine.

\section{Path of the steepest ascent experiment}

After having identified the three most significant variables through the PBD, the steepest ascent experiment was performed to move the experimental region of the response in the direction of the optimum, by appropriately changing the range of the selected variables. The path initiated from the design center of the factorial design (the screening design) and receded when no further improvement in the response could be achieved. When the maximum value was gained, that point could be considered as the center point for the optimization experimental design [31]. Table 4 summarizes the experimental design, the variables, and their values.

\section{Box-Behnken design}

The RSM is a collection of statistical tools and techniques for constructing and exploring a putative functional relationship between a response variable (i.e., plasmid yield) 
and a set of design variables (i.e., peptone, mannitol, and inoculum concentration). It is possible to derive an expression for performance measurement on the basis of the response values obtained from experiments using a particular combination of input variables [41]. In the present study, by employing BBD and RSM, the effects of the three independent variables (peptone, 24-28 g/L; mannitol, 7-9 g/L; inoculum concentration, $\mathrm{OD}=0.25-0.45$ ) and three levels (high, middle, and low) on the response (plasmid yield) were investigated to determine the optimal conditions, which maximized the yield of therapeutic DNA vaccine pcDNA-CCOL2A1 from shake cultivation. Each independent variable was coded at three levels: -1 , 0 , and +1 . The BBD comprised 17 experiments with five center points (to allow for estimation of pure error) and facilitated calculations of response function at intermediate levels, fitting a second-order response surface. Table 4 shows the variables and their values and the experimental design. This methodology allows for modeling of a second-order equation that describes the process. Plasmid production was analyzed through multiple regression analysis through the least squares method to fit the following equation:

$$
Y=\beta_{0}+\sum \beta_{\mathrm{i}} \mathrm{x}_{\mathrm{i}}+\sum \beta_{\mathrm{ij}} \mathrm{x}_{\mathrm{i}} \mathrm{x}_{\mathrm{j}}+\sum \beta_{\mathrm{ii}} \mathrm{x}_{\mathrm{i}}^{2}
$$

Where $Y$ is the measured response variable; $\beta_{0}, \beta_{\mathrm{i}}, \beta_{\mathrm{i}}$, and $\beta_{\mathrm{ii}}$ are constants and regression coefficients of the model, and $x_{i}$ and $x_{j}$ represent the independent variables in coded values. Data from the BBD for the optimization of plasmid production was subjected to second-order multiple regression analysis using the least squares method to obtain the parameter estimators of the mathematical model [18, 42]. Second-order multiple regression analysis was performed using the Design Expert software (Version 8.0.6, State-Ease Inc., Minneapolis, MN, USA) statistical package. The model was further assessed using ANOVA.

\section{Abbreviations \\ BBD: Box-Behnken design; BBD-RSM: Box-Behnken design-response surface method; CCOL2A1: Chicken type II procollagen; CIA: Collagen-induced arthritis; DMARDs: Disease-modifying antirheumatic drugs; MTX: Methotrexate; PBD: Plackett-Burman design; RA: Rheumatoid arthritis; RSM: Response surface method}

\section{Acknowledgements}

The authors thank the National Scientific and Technological Commission for funding this research.

\section{Funding}

This study was supported in part by a grant from the National Major Scientific and Technological Special Project for "Significant New Drug Development" (No.2009ZX09103-624 and No.2015GKS-072/139 to YZX). The funding agency played no role in the study design, data collection and analysis, decision to publish, or preparation of the manuscript.

\section{Availability of data and materials}

All data generated or analyzed during this study are included in this published article.

\section{Author's contributions}

YZX conceived the project, obtained grant support, designed research, and analyzed and interpreted data. $J \mathrm{~L}, \mathrm{XZ}, \mathrm{FL}, \mathrm{NL}$ and $\mathrm{YYS}$ performed the experiments, analysis, interpretation, statistic. $J \mathrm{~L}, \mathrm{XZ}$ and $\mathrm{YZX}$ wrote the paper and YZX revised the manuscript. All authors edited and approved the manuscript.

Ethics approval and consent to participate

Not applicable.

\section{Consent for publication}

This is an open-access article distributed under the terms of the Creative Commons Attribution Non-Commercial 4.0 International License (http://creativecommons.org/licenses/by-nc/4.0) which permits copy and redistribute the material just in non-commercial usages, provided the original work is properly cited.

\section{Competing interests}

The authors have no competing interest to declare in this work. The authors alone are responsible for the content and writing of the paper.

\section{Publisher's Note}

Springer Nature remains neutral with regard to jurisdictional claims in published maps and institutional affiliations.

Received: 26 April 2018 Accepted: 6 August 2018

Published online: 10 October 2018

\section{References}

1. Mallon S. DNA vaccines: Treatment options for autoimmune diseases. Microbiol Mol Gentics. 2008;4:99-103.

2. Robinson WH, Garren H, Utz PJ, Steinman L. Millennium Award. Proteomics for the development of DNA tolerizing vaccines to treat autoimmune disease. Clin Immunol. 2002;103:7-12.

3. Rosenthal KS, Mikecz K, Steiner HL 3rd, Glant TT, Finnegan A, Carambula RE, et al. Rheumatoid arthritis vaccine therapies: perspectives and lessons from therapeutic ligand epitope antigen presentation system vaccines for models of rheumatoid arthritis. Expert Rev Vaccine. 2015;14:891-908.

4. Singh JA, Saag KG, Bridges SL Jr, Akl EA, Bannuru RR, Sullivan MC, et al. 2015 American college of rheumatology guideline for the treatment of rheumatoid arthritis. Arthritis Rheumat. 2016;68:1-26.

5. Smolen JS, Landewé R, Bijlsma J, Burmester G, Chatzidionysiou K, Dougados $M$, et al. EULAR recommendations for the management of rheumatoid arthritis with synthetic and biological disease-modifying antirheumatic drugs: 2016 update. Ann Rheum Dis. 2017;76:960-77.

6. Mclnnes IB, Schett G. Mechanisms of disease: The pathogenesis of rheumatoid arthritis. NEJM. 2011;365:2205-19.

7. Holmdahl R, Malmström V, Burkhardt H. Autoimmune priming, tissue attack and chronic inflammation - the three stages of rheumatoid arthritis. Eur J Immunol. 2014;44:1593-9.

8. Song XQ, Liang F, Liu N, Luo Y, Yuan F, Xue H, et al. Therapeutic efficacy of experimental rheumatoid arthritis with low-dose methotrexate by increasing partially CD4+CD25+Treg cells and inducing Th1 toTh2 shift in both cells and cytokines. Biomed Pharmacother. 2010;64:463-71.

9. Song XQ, Liang F, Liu N, Luo Y, Xue H, Yuan F, et al. Construction and characterization of a novel DNA vaccine that is potent antigen-specific tolerizing therapy for experimental arthritis by increasing CD4+CD25+Treg cells and inducing Th1 to Th2 shift in both cells and cytokines. Vaccine. 2009;27:690-700.

10. Long J, ZhaoX YS, Zhang ZJ, Jin J, Yu K, et al. Safety and immunogenicity of a novel therapeutic DNA vaccine encoding chicken type II collagen for rheumatoid arthritis in normal rats. Hum Vaccines Immunother. 2015;11: 2777-84.

11. Zhao X, Long J, Yun S, Zhang ZJ, Jin J, Yu K, et al. Evaluation of humoral and cellular immune responses to a DNA vaccine encoding chicken type ॥ collagen for rheumatoid arthritis in normal rats. Hum Vaccines Immunother. 2015;11:938-45.

12. Zhao $X$, Long J, Liang F, Liu N, Sun YY, Xi YZ. Dynamic profiles, biodistribution and integration evaluation of a novel therapeutic DNA vaccine encoding CCOL2A1for rheumatoid arthritis in normal rat. Vaccine. 2018; (in press) 
13. Long J, Zhao X, Yuan F, Liang F, Liu N, Sun YY, et al. Genetic stability of an Escherichia coli strain engineered to produce a novel therapeutic DNA vaccine encoding chicken type II collagen for rheumatoid arthritis. Process Biochem. 2017:52:86-93.

14. Carnes AE. Fermentation design for the manufacture of therapeutic plasmid DNA. Bio Process Intern. 2005;3:36-44.

15. Cai $Y$, Rodriguez $S$, Hebel H. DNA vaccine manufacture: scale and quality. Expert Rev Vaccine. 2009;8:1277-91.

16. Williams JA, Luke J, Langtry S, Anderson S, Hodgson CP, Carnes AE. Generic plasmid DNA production platform incorporating low metabolic burden seed-stock and fed-batch fermentation processes. Biotechnol Bioeng. 2009; 103:1129-43.

17. Balusu R, Paduru RR, Kuravi S, Seenayya G, Reddy G. Optimization of critical medium components using response surface methodology for ethanol production from cellulosic biomass by Clostridium thermocellum SS19. Process Biochem. 2005:40:3025-30.

18. Cui FJ, Zhao LM. Optimization of xylanase production from Penicilliumsp. WX-Z1 by a two-step statistical strategy: Plackett-Burman and box-Behnken experimental design. Int J Mol Sci. 2012;13:10630-46.

19. Salihu A, Alam MZ, AbdulKarim MI, Salleh HM. Optimization of lipase production by Candida cylindracea in palm oil mill effluent based medium using statistical experimental design. J Mol Catal Enzym. 2011;69:66-73.

20. Cui FJ, Liu ZQ, Li Y, Ping LF, Ping LY, Zhang ZC, et al. Production of mycelia biomass and exo-polymer by Hericiumerinaceus CZ-2: Optimization of nutrients levels using response surface methodology. Biotechnol Bioproc. 2010;15:299-307.

21. Periyasamy AK, Muthu M, Kannan V. Optimization of nutrients for the production of RNase by Bacillus firmus VKPACU1 using response surface methodology. Biotechnol Bioprocess. 2010;14:202-6.

22. Kanmani $P$, Kumar RS, Yuvaraj N, Paari KA, Pattukumar $V$, Arul V. Optimization of media components for enhanced production of Streptococcus phocaePI80 and its bacteriocin using response surface methodology. Braz J Microbiol. 2011;42:716-20.

23. Preetha R, Jayaprakash NS, Philip R, Singh ISB. Optimization of medium for the production of a novel aquaculture probiotic, Micrococcus MCCB 104 using central composite design. Biotechnol Bioprocess Eng. 2007;12:548-55.

24. Goncalves GA, Prather KL, Monteiro GA, Prazeres DM. Engineering of Escherichia coli strains for plasmid biopharmaceutical production: scale-up challenges. Vaccine. 2014;32:2847-50.

25. Yau SY, Keshavarz-Moore E, Ward J. Host strain influences on supercoiled plasmid DNA production in Escherichia coli: implications for efficient design of large-scale processes. Biotechnol Bioeng. 2008;101:529-44.

26. Jaén KE, Lara AR, Ramírez OT. Effect of heating rate on pDNA production by E. coli. Biochem Eng J. 2013;79:230-8.

27. Lara AR, Knabben I, Regestein L, Sassi J, Caspeta L, Ramírez OT, et al. Comparison of oxygen enriched air vs. pressure cultivations to increase oxygen transfer and to scale-up plasmid DNA production fermentations. Eng Life Sci. 2011;11:382-6.

28. Wunderlich M, Taymaz-Nikerel H, Gosset G, Ramírez OT, Lara AR. Effect of growth rate on plasmid DNA production and metabolic performance of engineered Escherichia coli strains. J Biosci Bioeng. 2014;117:336-42.

29. Bohle K, Ross A. Plasmid DNA production for pharmaceutical use: role of specific growth rate and impact on process design. Biotechnol Bioeng. 2011;108:2099-106.

30. Zheng S, Friehs K, He N, Deng X, Li Q, He Z, et al. Optimization of medium components for plasmid production by recombinant $E$. coli $\mathrm{DH} 5 \mathrm{a}$ pUK21CMVB1.2. Biotechnol Bioprocess Eng. 2007;12:213-21.

31. Gao H, Liu M, Liu JT, Dai HQ, Zhou XL. Medium optimization for the production of avermectin B1a by Streptomyces avermitilis 14-12A using response surface methodology. Bioresour Techol. 2009;100:4012-6.

32. Lopes MB, Martins G, Calado CRC. Kinetic modeling of plasmid bioproduction in Escherichia coli DH5a cultures over different carbon-source compositions. J Biotechnol. 2014;186:38-48.

33. O'Mahony K, Freitag R, Hilbrig F, Müller P, Schumacher I. Strategies for high titre plasmid DNA production in Escherichia coli DH5a. Process Biochem. 2007:42:1039-49.

34. Silva F, Queiroz JA, Domingues FC. Evaluating metabolic stress and plasmid stability in plasmid DNA production by Escherichia coli. Biotechnol Adv. 2012;30:691-708

35. Carnes $A E$, Williams JA. Plasmid DNA manufacturing technology. Recent Pat Biotechnol. 2007;1:151-66.
36. Singer A, Eiteman MA, Altman E. DNA plasmid production in differenthost strains of Escherichia coli. J Ind Microbiol Biotechnol. 2009;36:521-30.

37. Listner K, Bentley L, Okonkowski J, Kistler C, Wnek R, Caparoni A, et al. Development of a highly productive and scalable plasmid DNA production platform. Biotechnol Prog. 2006;222:1335-45.

38. Carnes AE, Hodgson CP, Williams JA. Inducible Escherichia coli fermentation for increased plasmid DNA production. Biotechnol Appl Biochem. 2006;45: 155-66.

39. Xi CX, Liu N, Liang F, Guo SQ, Sun YY, Yang F, et al. Molecular cloning: characterization and localization of chicken type II procollagen gene. Gene. 2006;366:67-76.

40. Sambrook J, Russwell DW. Molecular Cloning: A Laboratory Manual, 2001, 3rd ed. by Cold Spring Harbor Laboratory Press.

41. Li Q, Li YM, Han S, Liu YZ, Song DX. Optimization of fermentation conditions and properties of an exopolysaccharide from Klebsiella sp. H-207 and application in adsorption of hexavalent chromium. PLoS One. 2013;8:1-11.

42. Ren X, He L, Cheng J, Chang J. Optimization of the solid-state fermentation and properties of a polysaccharide from paecilomyces cicadae (Miquel) samson and its antioxidant activities in vitro. PLoS One. 2014:e87578.
Ready to submit your research? Choose BMC and benefit from:

- fast, convenient online submission

- thorough peer review by experienced researchers in your field

- rapid publication on acceptance

- support for research data, including large and complex data types

- gold Open Access which fosters wider collaboration and increased citations

- maximum visibility for your research: over $100 \mathrm{M}$ website views per year

At $\mathrm{BMC}$, research is always in progress.

Learn more biomedcentral.com/submissions 